\title{
Hematological and Biochemical Blood Changes In Chronic Tendinitis Thoroughbred Race Horses
}

\author{
${ }^{1}$ Tmumen, S.K ${ }^{*},{ }^{2}$ Anwar M. Abdalmula, ${ }^{3}$ Fahima A. alnagar \\ ${ }^{1}$ Department of Surgery \& Theriogenology, Faculty of Veterinary Medicine, University of Tripoli, Libya \\ ${ }^{2}$ Department of Physiology, Biochemistry and Nutrition, Faculty of Veterinary Medicine, University of \\ Tripoli, Libya \\ ${ }^{3}$ Department of Biochemistry, Faculty of Medicine, University of Tripoli, Libya
}

\begin{abstract}
Tendon injury is the most important veterinary reason for wastage of thoroughbred racehorses. Clinical diagnosis of tendon injuries is confirmed by a combination of clinical, ultrasonographic or post mortem examination of the injured limb. In addition, measurement of hematological and biochemical blood parameters are an important tool that aid health assessment and decision-making in diagnosis, treatment and follow-up of the injured tendon. Therefore, the lack of information or misinterpretation of these parameters may affect the accuracy of disease diagnosis and then lead to poor treatment. The present study was conducted to evaluate the levels of some hematological and biochemical parameter in the blood of thoroughbred horses affected by chronic tendinitis and compared with normal horses. Blood samples were collected from 15 healthy thoroughbred horses ( 8 stallions and 7 mares) and 21 tendinitis thoroughbred horses (11 stallions and 10 mares); and the levels of 18 blood parameters were determined. The tendinitis horses had higher number of erythrocytes and thrombocytes, higher values of packed cell volume (PCV) and mean corpuscular volume (MCV); lower enzyme activity of creatine kinase (CK), lower values of lactic acid (LA), icteric index and mean corpuscular hemoglobin concentration (MCHC) and lower numbers of band neutrophils than the normal horses. The chronic tendinitis mares had higher number of thrombocytes and lower values of lactate dehydrogenase (LDH) enzyme activity, lactic acid, plasma proteins, MCHC and lower numbers of white blood cells (WBC) than the normal mares. The chronic tendinitis stallions had higher levels of lactic acid, plasma proteins, MCV, and higher numbers of erythrocytes and lower values of icteric jaundice, MCHC, band neutrophils than the normal horses. No significant differences were reported when tendinitis mares were compared with tendinitis males. However, normal mares showed higher levels of plasma proteins than normal stallions. The results obtained by this study can be used as useful index to diagnose and treat chronic tendinitis in horses.
\end{abstract}

Keywords: Thoroughbred, Chronic tendinitis, Hematology and Biochemistry, Blood changes.

\section{Introduction}

Tendons are elastic structures which passively transfer force generated by muscles to their bony attachments on the opposite side of a joint to allow movement. They are composed of tightly packed, parallel collagen fibers, which give tendons their huge tensile strength (Sjaastad et al., 1997, 2010).

The equine athlete undergoes significant musculoskeletal changes during conditioning and competition which may lead to race retirement (Lam et al., 2007). Injury accidents of tendons are common in all athletic activities in both humans and horses (Wang et al., 2006). Unfortunately, Lameness in the athletic horse is the most common cause of loss of use (Dyson et al., 2008; Jeffcott et al., 1982; Perkins, Reid and Morris, 2004). Therefore, tendinopathy remains a significant cause of wastage in thoroughbred race horses and a major health and welfare concern, as it is a debilitating and potentially career-ending injury (Dowling et al., 2000; Perkins et al, 2004).

Tendinitis is the term used for chronic tendon injuries in human and horses (Alfredson et al., 2003). It is more likely to be seen in the forelimb than hind limb, with the flexor tendons most commonly affected ones (McIlwraith et al., 2018) and the tendinitis of the forelimb is the most common musculoskeletal injuries and 
causes of wastage in the performance ability of horses, specially the superficial digital flexor tendon (SDFT) (Genovese et al., 1985; Goodship et al., 1994; Gillis, 1997; Patterson-Kane et al., 1998; Dahlgren et al., 2001; Patterson-Kane C. et al., 2009; Thorpe et al., 2010). Tendon lesions are usually accompanied by enlargement of the affected area and a decrease in tendon's elastic modulus and maximal stress (CrevierDenoix et al., 1997). Tendinitis usually leads to lameness which associated with muscular fatigue, lack of vascular supply and collagen fiber ruptures due to overstrain of the tendon with recurrent overload during exercise (Kraus-Hansen et al., 1992). It is also followed by a long layoff period for tendon healing and rehabilitation, resulting in great financial loss in equestrian competitive sports (Marxen et al., 2004; Kraushansen et al., 1992; Patterson-Kane et al., 1998; Patterson-Kane et al., 1997; Cherdchutham et al., 2001; Oikawa and Kasashima, 2002). The SDFT resistance can be easily exceeded if the horse is fatigued or showed in an uncoordinated manner, usually lead to partial or total rupture (Batson et al., 2003). Moreover, factors related to poor limb conformation, inadequate trimming and shoeing, excessive weight, and inappropriate exercise performance may also be another cause of tendon injury (Gillis, 1997).

Hematological and biochemical analysis of blood have been commonly used to evaluate many diseases in horses and other animals (Radostits et al, 1994; Kaneko, 1989). Blood analysis is an important way to detect the pathological changes caused by an illness and help clinicians to diagnose and then treat these changes. The hematological parameters may include erythrocyte counts, packed cell volume (PCV), hemoglobin concentration $(\mathrm{Hb})$, erythrocyte sedimentation rate (ESR) and fragility, mean corpuscular values (MCV), total and differential leukocyte count, platelet count (Schalm et al., 1975). These erythrocytic indices are used to determine whether an animal is normal or anemic, while the assessment of leukocytic profile enables the clinician to evaluate the animal's response to the infectious agents, toxic chemicals and physical injury (Coles, 1986; Ihedioha and Chineme, 2004). Moreover, platelets function primarily in hemostasis (blood clotting) and their important role in the stop of bleeding following blood vessel injury (Ihedioha et al., 2004). The assessment of the serum or plasma biochemical parameters in animals is important in predicting pathological changes in vital internal organs of the body such as liver, kidney, pancreas, heart and muscles (Coles, 1986). The most important parameters of blood biochemistry used in the clinical assessment of horse diseases include determination of serum activity of enzymes such as aspartate amino transferase (AST), alkaline phosphatase (ALP) and lactate dehydrogenase (LDH); evaluation of synthetic activity of the liver by measuring the total proteins, albumin, serum cholesterol and bilirubin, and assessment of serum indicators of renal function such as creatine and urea nitrogen (Coles, 1986). The levels of these blood parameters give an indication of the health condition of the evaluated animal. In this context, this study was conducted to determine the values of some hematological and serum biochemical parameters in chronic tendinitis horses and compare these values with the levels of the same parameters measured in healthy adult horses.

\section{Material and Methods}

\section{Animals}

A total of 36 thorougbred horses located in the different racing stable round kualalumpor, (Malaysia) were used in this study. Twenty one horses (11 stallions and 10 mares) were diagnosed with chronic tendinitis and fifteen horses ( 8 stallions and 7 mares) were healthy and used as a control group. During the acute stage, the tendinitis horse is usually severely lame and the involved structures are hot, painful, and swollen. In chronic cases, there is usually fibrosis with thickening and adhesions in the peritendinous area. The horse diagnosed with chronic tendinitis may go sound while walking or trotting, but lameness may recur under hard work. Ultrasonography delineates the cross-sectional and longitudinal extent of the tendinitis.

\section{Blood collection and analysis}

Blood samples were obtained from all horses via jugular venipuncture into ethyl diaminotetra-acetic acid (EDTA) containing vacutainer tubes for hematological tests and into heparinized vacutainer tubes for biochemical analysis. Blood sample collection was performed immediately after a 20 min recovery period. The collected blood samples were immediately analysed in a laboratory located in the faculty of veterinary medicine at Universiti Putra Malaysia (UPM). Hematological analysis included measurement of haemoglobin concentration $(\mathrm{g} / \mathrm{l})$, packed-cell volume $(1 / 1)$, counts of red blood cells $(\mathrm{x} 1012 / 1)$ and white blood cells (x/109/1), mean corpuscular volume (fL), mean corpuscular volume(MCV) (g/l), and mean 
corpuscular hemoglobin concentration (MCHC) (g/l) were analysed using Cell DYN 3700, Abbot (Abbott Diagnostics, Abbott Park, Illinois,USA). The packed cell volume (PCV) was analysed using HettichHematocrit 210 (Hettich Instruments, Beverly, MA, USA) and Hawksley microhematocrit reader (Hettich Instruments, Beverly, Ramsey, MA, USA). Biochemical analysis included measurement of the concentration of plasma protein $(\mathrm{g} / \mathrm{l})$, icteric index (units) and Lactate ( $\mathrm{mmol} / \mathrm{l}$ ); and the enzyme activity (units/l) of creatine kinase $(\mathrm{CK})$ and lactate dehydrogenase $(\mathrm{LDH})$ were determined with chemistry analyzer (Hitachi 920, Hitachi High-Technologies Corporation, Japan) using standard diagnostic kits (Roche diagnostics Corporation, Indianapolis, IN, USA).

\section{Statistical analysis}

Data were analysed using GraphPad Prism statistical software (version 6.0b; GraphPad Software Inc, La Jolla, CA, USA). Results are expressed as mean \pm SEM. Analysis of data between groups was performed using Mann Whitney test and statistical significance between groups was accepted at $\mathrm{p}<0.05$.

\section{Results}

The mean \pm SEM values of some blood hematological and biochemical parameters of both chronic tendinitis and normal thoroughbred horses are shown in table (1). It showed that the tendinitis horses had higher number of erythrocytes and thrombocytes; and higher levels of PCV and MCV than the normal horses. However, the tendinitis horses showed lower CK enzyme activity, lower levels of lactic acid, icteric jaundice and MCHC; and lower numbers of band neutrophils than the normal horses.

Although the sex factor did not reveal significant differences within the tendinitis and healthy horse groups (with the exceptions of that the normal mares had higher plasma proteins $(67.14 \pm 1.14)$ than the normal stallions (62.25 \pm 0.79 ), data not shown), the tendinitis mares, as shown in table (2), showed higher number of thrombocytes and lower LDH enzyme activity, lower levels of lactic acid, plasma proteins, MCHC and lower numbers of WBC than the normal mares. Moreover, the tendinitis stallions, as shown in table (3), showed higher levels of lactic acid, plasma proteins and MCV; and higher numbers of erythrocytes than the normal ones. On the other hands, tendinitis stallions had lower levels of icteric jaundice and MCHC and lower numbers of band neutrophils than the normal stallions.

Table 1: Mean \pm SEM. of some biochemical and hematological blood parameters

\begin{tabular}{|l|c|c|c|}
\hline \multicolumn{1}{|c|}{ Parameter } & Unit & Tendinitis & Normal \\
\hline CK & $\mathrm{UL}^{-1}$ & $130 \pm 6.91 \mathrm{a}$ & $162.5 \pm 11.87 \mathrm{~b}$ \\
\hline LDH & $\mathrm{UL}^{-1}$ & $390.6 \pm 23.66 \mathrm{a}$ & $456.1 \pm 41.90 \mathrm{a}$ \\
\hline Lactate & $\mathrm{mmol} / 1$ & $1.42 \pm 0.09 \mathrm{a}$ & $2.10 \pm 0.11 \mathrm{~b}$ \\
\hline Icteric index & $\mathrm{Units}$ & $17.25 \pm 3.27 \mathrm{a}$ & $21.79 \pm 1.44 \mathrm{~b}$ \\
\hline Plasma proteins & $\mathrm{g} / 1$ & $64.19 \pm 0.58 \mathrm{a}$ & $64.53 \pm 0.92 \mathrm{a}$ \\
\hline RBC & $10^{12} / 1$ & $8.15 \pm 0.21 \mathrm{a}$ & $7.31 \pm 0.18 \mathrm{~b}$ \\
\hline Hb & $\mathrm{gl}$ & $124.8 \pm 2.74 \mathrm{a}$ & $121.8 \pm 1.90 \mathrm{a}$ \\
\hline PCV & 11 & $0.37 \pm 0.007 \mathrm{a}$ & $0.35 \pm 0.004 \mathrm{~b}$ \\
\hline MCV & $\mathrm{fL}$ & $46.86 \pm 0.58 \mathrm{a}$ & $44.67 \pm 0.43 \mathrm{~b}$ \\
\hline MCHC & $\mathrm{g} / 1$ & $327.5 \pm 4.12 \mathrm{a}$ & $373.1 \pm 4.17 \mathrm{~b}$ \\
\hline WBC & $10^{9} / 1$ & $8.68 \pm 0.39 \mathrm{a}$ & $9.86 \pm 0.58 \mathrm{a}$ \\
\hline Band neutrophils & $10^{9} / 1$ & $0.15 \pm 0.07 \mathrm{a}$ & $0.38 \pm 0.07 \mathrm{~b}$ \\
\hline Seg neutrophils & $10^{9} / 1$ & $5.98 \pm 0.40 \mathrm{a}$ & $7.08 \pm 0.46 \mathrm{a}$ \\
\hline Lymphocytes & $10^{9} / 1$ & $2.40 \pm 0.21 \mathrm{a}$ & $2.20 \pm 0.18 \mathrm{a}$ \\
\hline Monocytes & $10^{9} / 1$ & $0.09 \pm 0.02 \mathrm{a}$ & $0.04 \pm 0.02 \mathrm{a}$ \\
\hline Eosinophils & $10^{9} / 1$ & $0.08 \pm 0.03 \mathrm{a}$ & $0.14 \pm 0.10 \mathrm{a}$ \\
\hline Basophils & $10^{9} / 1$ & $0.01 \pm 0.01 \mathrm{a}$ & $0.00 \pm 0.00 \mathrm{a}$ \\
\hline
\end{tabular}




\begin{tabular}{|l|c|c|c|}
\hline Thrombocytes & $10^{9} / 1$ & $263.1 \pm 28.26 \mathrm{a}$ & $161.3 \pm 8.77 \mathrm{~b}$ \\
\hline
\end{tabular}

Values were analysed using Mann Whitney test and values with different letters in the same row are significantly different with $\leq 0.05$

Table 2: Mean \pm SEM of some biochemical and hematological parameters

\begin{tabular}{|l|c|c|c|}
\hline \multicolumn{1}{|c|}{ Parameter } & Unit & Tendinitis & Normal \\
\hline CK & $\mathrm{UL}^{-1}$ & $126.0 \pm 11.74 \mathrm{a}$ & $170.0 \pm 21.76 \mathrm{a}$ \\
\hline LDH & $\mathrm{UL}^{-1}$ & $357.7 \pm 36.35 \mathrm{a}$ & $530.2 \pm 76.13 \mathrm{~b}$ \\
\hline Lactate & $\mathrm{mmol} / 1$ & $1.36 \pm 0.16 \mathrm{a}$ & $2.31 \pm 0.15 \mathrm{~b}$ \\
\hline Icteric index & Units & $19.44 \pm 7.19 \mathrm{a}$ & $20.83 \pm 2.71 \mathrm{a}$ \\
\hline Plasma proteins & $\mathrm{g} / 1$ & $63.20 \pm 0.67 \mathrm{a}$ & $67.14 \pm 1.14 \mathrm{~b}$ \\
\hline RBC & $10^{12} / 1$ & $7.98 \pm 0.30 \mathrm{a}$ & $7.48 \pm 0.35 \mathrm{a}$ \\
\hline Hb & $\mathrm{gll}$ & $123.2 \pm 3.96 \mathrm{a}$ & $125.0 \pm 3.17 \mathrm{a}$ \\
\hline PCV & $1 \mathrm{l}$ & $0.36 \pm 0.01 \mathrm{a}$ & $0.35 \pm 0.007 \mathrm{a}$ \\
\hline MCV & $\mathrm{fL}$ & $46.80 \pm 1.13 \mathrm{a}$ & $45.43 \pm 0.71 \mathrm{a}$ \\
\hline MCHC & $\mathrm{g} / 1$ & $331.5 \pm 6.00 \mathrm{a}$ & $369.6 \pm 8.84 \mathrm{~b}$ \\
\hline WBC & $10^{9} / 1$ & $8.15 \pm 0.52 \mathrm{a}$ & $10.03 \pm 0.36 \mathrm{~b}$ \\
\hline Band neutrophils & $10^{9} / 1$ & $0.10 \pm 0.05 \mathrm{a}$ & $0.37 \pm 0.14 \mathrm{a}$ \\
\hline Seg neutrophils & $10^{9} / 1$ & $5.40 \pm 0.73 \mathrm{a}$ & $7.22 \pm 0.50 \mathrm{a}$ \\
\hline Lymphocytes & $10^{9} / 1$ & $2.44 \pm 0.35 \mathrm{a}$ & $2.37 \pm 0.27 \mathrm{a}$ \\
\hline Monocytes & $10^{9} / 1$ & $0.0 .08 \pm 0.03 \mathrm{a}$ & $0.02 \pm 0.02 \mathrm{a}$ \\
\hline Eosinophils & $10^{9} / 1$ & $0.08 \pm 0.04 \mathrm{a}$ & $0.02 \pm 0.02 \mathrm{a}$ \\
\hline Basophils & $10^{9} / 1$ & $0.02 \pm 0.02 \mathrm{a}$ & $0.00 \pm 0.00 \mathrm{a}$ \\
\hline Thrombocytes & $10^{9} / 1$ & $227.4 \pm 39.59 \mathrm{a}$ & $150.3 \pm 11.83 \mathrm{~b}$ \\
\hline
\end{tabular}

Values were analysed using Mann Whitney test and values with different letters in the same row are significantly different with $\mathrm{p} \leq 0.05$.

Table 3: Mean \pm SEM of some biochemical and hematological parameters

\begin{tabular}{|l|c|c|c|}
\hline Parameter & Unit & Tendinitis & Normal \\
\hline CK & $\mathrm{UL}^{-1}$ & $133.6 \pm 8.19 \mathrm{a}$ & $155.4 \pm 12.56 \mathrm{a}$ \\
\hline LDH & $\mathrm{UL}^{-1}$ & $420.6 \pm 29.48 \mathrm{a}$ & $391.3 \pm 30.84 \mathrm{a}$ \\
\hline Lactate & $\mathrm{mmol} / \mathrm{l}$ & $2.63 \pm 1.14 \mathrm{a}$ & $1.92 \pm 0.13 \mathrm{~b}$ \\
\hline Icteric index & Units & $15.45 \pm 1.57 \mathrm{a}$ & $22.50 \pm 1.63 \mathrm{~b}$ \\
\hline Plasma proteins & $\mathrm{g} / \mathrm{l}$ & $65.09 \pm 0.86 \mathrm{a}$ & $62.25 \pm 0.79 \mathrm{~b}$ \\
\hline RBC & $10^{12} / 1$ & $8.30 \pm 0.30 \mathrm{a}$ & $7.15 \pm 0.14 \mathrm{~b}$ \\
\hline Hb & $\mathrm{gll}$ & $126.5 \pm 4.01 \mathrm{a}$ & $119.0 \pm 1.89 \mathrm{a}$ \\
\hline PCV & $1 \mathrm{l}$ & $0.37 \pm 0.01 \mathrm{a}$ & $0.34 \pm 0.004 \mathrm{a}$ \\
\hline MCV & $\mathrm{fL}$ & $46.91 \pm 0.51 \mathrm{a}$ & $44.00 \pm 0.42 \mathrm{~b}$ \\
\hline MCHC & $\mathrm{g} / 1$ & $323.8 \pm 5.72 \mathrm{a}$ & $376.1 \pm 1.96 \mathrm{~b}$ \\
\hline WBC & $10^{9} / 1$ & $16.95 \pm 7.82 \mathrm{a}$ & $9.71 \pm 1.09 \mathrm{a}$ \\
\hline Band neutrophils & $10^{9} / 1$ & $0.19 \pm 0.14 \mathrm{a}$ & $0.39 \pm 0.07 \mathrm{~b}$ \\
\hline Seg neutrophils & $10^{9} / 1$ & $6.39 \pm 0.44 \mathrm{a}$ & $6.96 \pm 0.79 \mathrm{a}$ \\
\hline Lymphocytes & $10^{9} / 1$ & $2.38 \pm 0.28 \mathrm{a}$ & $2.04 \pm 0.24 \mathrm{a}$ \\
\hline Monocytes & $10^{9} / 1$ & $0.10 \pm 0.04 \mathrm{a}$ & $0.06 \pm 0.03 \mathrm{a}$ \\
\hline Eosinophils & $10^{9} / 1$ & $0.08 \pm 0.06 \mathrm{a}$ & $0.24 \pm 0.20 \mathrm{a}$ \\
\hline
\end{tabular}




\begin{tabular}{|l|c|c|c|}
\hline Basophils & $10^{9} / 1$ & $0.00 \pm 0.00 \mathrm{a}$ & $0.00 \pm 0.00 \mathrm{a}$ \\
\hline Thrombocytes & $10^{9} / 1$ & $295.6 \pm 39.30 \mathrm{a}(\mathrm{p}=0.0506)$ & $171.0 \pm 12.45 \mathrm{a}$ \\
\hline
\end{tabular}

Values were analysed using Mann Whitney test and values with different letters in the same row are significantly different with $\mathrm{p} \leq 0.05$.

\section{Discussion}

The thoroughbred horse breed was established in England by crosses between stallions of Arabian origin and a poorly defined group of mares in the early 1700s (Binns et al., 2010). The racing of thoroughbred evolved in England over two centuries ago and is practiced now in over many countries (O'Sullivan et al., 2013). Thoroughbred racing requires an understanding of both the veterinary aspects of thoroughbred horse's care, and the dynamics and economics of the racing industry (Gupta et al., 1993; Lam et al., 2007; O'Sullivan et al., 2013). Termination of a racing career to a horse may result from veterinary medical advice pertaining to injury or disease and an assessment of athletic ability (Smith et al., 2003; Lam et al., 2007).

To reach full assesment of a disease, measurment of biochemical and hematological blood parameters are widely used in veterinary clinics to provide more informations that can aid the practitioners and veterinarians in the differential diagnosis, nutritional and therapeutic monitoring of racehorse's diseases with more accuracy and vidality (Schalm et al., 1975; Snow, 1985; Snow and Harris, 1985; Gupta et al., 1993). Measurment of these parameters also contribute to the welfare and improvement of racehorse physical fitness and performance (Ricketts, 2004). Therefore, for better interpretation of these blood parameters, it is necessary to measure these values in apparently healthy subjects in the view to make out the physiological values from the pathological ones.

The present study, investigated the haematological and biochemical blood changes caused by chronic tendinitis in thouroughbred horses and compared these changes with the normal levels in healthy thouroughbred horses. In addition, the sex effect was investigated within and between the tendenitis and the healthy horse groups. To the best knowledge of the authors, this is the first study which documented the levels of some hematological and biochemical parameteres in chronic tendinitis thouroughbred horses. The normal hematological and biochemical paramters of thourghbred horses were previousley investigated and in both sexes (Aoki et al., 2012).

Hematological analysis in this study reported higher number of erythrocytes, PCV and MCV in tendinitis horses than the normal horses. The increase of RBC numbers may be attributed to the release of erythrocytes into the circulation as a result of splenic contraction (Persson, 1967).

The tendinitis horses showed lower CK enzyme activity, lactic acid levels and icteric index than the normal horses in this study. A previouse study showed that CK enzyme reach the peak level of activity at 6-12 $\mathrm{h}$ of exercise and return to baseline by 3-4 days, assuming that no further myopathy occurs (Siciliano et al., 1995). The possible reason of the observed lower level of the CK enzyme activity in the tendenitis group than the normal one may be due to a consequence of diminished efflux of the muscle enzyme into serum from reduced physical activity caused by illness or advanced age or may result from reduced muscle mass accompanying muscle wasting or cachectic states (Rosalki, 1998). It is well known that the lactic acid level is used in practice to evaluate the fitness of racehorses and used as an indicator of racing performance (Harkins et al., 1993; Lindner, 2000). The changes in the rate of the LA production by muscles, reflect the degree at which anaerobic glycolysis contributes to the total energy production (Pösö, 2002) and the decline in blood lactate concentration reflects the cessation of exercise in chronic tendinitis horses due to the tendon injury. The lower values of icteric index reported in tendinitis than the normal horses may be attributed to the.interference with biochemistry assays due to haemolysis, icterus or lipaemia (HIL) which is a common problem in clinical laboratory practice which is measured by icteric index (Simundic et al., 2009; Adiga, 2016; Farrell et al., 2016). This index is also used to detect patients with total bilirubin values above the reference range (Farrell et al., 2016). The interpretation of the icteric index value reflects that the higher the icteric index, the greater is the HIL. Therofre, the low level of icteric index in tendinitis group reflect that there was less HIL than that of normal.

Sex factor had no effect within the two studied horse groups (with the exception of the reported high plasma proteins in the normal mares compared to the normal stallions, data not shown). The level of total plasma 
proteins is used to detect some changes of physiological and pathological condition. The low total protein level is an indication of dehydration, inflammation and infection, wheras the high level is an indication of the starvation, gastrointestianal (GI) disease and liver or kidney disease (Watson, 2016). However, the values of many blood parameters differed significantly when the same sex animals of both tendinitis and control horse groups were compared. The tendinitis mares had higher number of thrombocytes than the normal mares. This increase of plateletes may be due to bacterial infection (Barrelet et al., 2002; Watson, 2016). Lower LDH enzyme activity, lower levels of lactic acid, plasma proteins, MCHC and lower numbers of WBC were reported in tendintis mares than the normal mares. In the other sex, higher levels of LA, plasma proteins, MCV, and higher erythrocytes numbers were reported in tendinitis stallions than the normal ones. Furtheromre, tendinitis stallions had lower levels of icteric jaundice, MCHC and band neutrophils than their normal counterparts.

The present study, to the best of the author knowledge, provides the literature with the first evidence that the chronic tendinitis can affect the normal levels of many haematological and biochemical blood parameters in thouroughbred horses. More investigation on more biochemical blood parameters are required.

\section{Acknowledgments}

The authors would like to thank Dr. Rasedee Abdullah and Dr. Bashir Ahmad Fateh Mohamed, Universiti Putra, Malaysia (UPM) for their assessment and use of their equipment and tolls, and also their kindness help and support.

\section{References}

[1.] Adiga, U. S. (2016) 'Icteric index and its significance', 2(4), pp. 32-34.

[2.] Alfredson, $H$. et al. (2003) 'cDNA-arrays and real-time quantitative PCR techniques in the investigation of chronic achilles tendinosis', Journal of Orthopaedic Research, 21(6), pp. 970-975. doi: 10.1016/S0736-0266(03)00107-4.

[3.] Aoki, T. and Ishii, M. (2012) 'Hematological and Biochemical Profiles in Peripartum Mares and Neonatal Foals (Heavy Draft Horse)', Journal of Equine Veterinary Science. Elsevier Inc., 32(3), pp. 170-176. doi: 10.1016/j.jevs.2011.08.015.

[4.] Barrelet, A., Hospital, R. E. and Centre, D. (2002) 'Haemnatology and blood biochemnistry in the horse : a guide to interpretation', (June 2002). doi: 10.1136/inpract.24.6.318.

[5.] Batson, E. L. et al. (2003) 'Are the material properties and matrix composition of equine flexor and extensor tendons determined by their functions?', Equine Veterinary Journal, 35(3), pp. 314-318. doi: 10.2746/042516403776148327.

[6.] Binns, M. M., Boehler, D. A. and Lambert, D. H. (2010) 'Identification of the myostatin locus (MSTN) as having a major effect on optimum racing distance in the Thoroughbred horse in the USA', Animal Genetics, 41(SUPPL. 2), pp. 154-158. doi: 10.1111/j.1365-2052.2010.02126.x.

[7.] Cherdchutham, W. et al. (2001) 'Effects of exercise on the diameter of collagen fibrils in the central core and periphery of the superficial digital flexor tendon in foals', American Journal of Veterinary Research, 62(10), pp. 1563-1570. doi: 10.2460/ajvr.2001.62.1563.

[8.] Coles, E. H. (1986) 'Veterinary clinical pathology', in. Philadelphia: Saunders WB.

[9.] Crevier-Denoix, N. et al. (1997) 'Mechanical properties of pathological equine superficial digital flexor tendons.', Equine veterinary journal. Supplement, 23(23), pp. 23-26. doi: 10.1111/j.20423306.1997.tb05046.x.

[10.] Dahlgren, L. A., Nixon, A. J. and Brower-Toland, B. D. (2001) 'Effects of $\beta$-aminopropionitrile on equine tendon metabolism in vitro and on effects of insulin-like growth factor-I on matrix production by equine tenocytes', American Journal of Veterinary Research, 62(10), pp. 15571562. doi: 10.2460/ajvr.2001.62.1557.

[11.] Dowling, B. A. et al. (2000) 'Review Article Superficial digital flexor tendonitis in the horse', 32, pp. 369-378.

[12.] Dyson, P. K. et al. (2008) 'Days lost from training by two- and three-year-old Thoroughbred horses: A survey of seven UK training yards', Equine Veterinary Journal, 40(7), pp. 650-657. doi: 10.2746/042516408X363242.

[13.] Farrell, C. J. L. and Carter, A. C. (2016) 'Serum indices: managing assay interference', Annals of Clinical Biochemistry, 53(5), pp. 527-538. doi: 10.1177/0004563216643557. 
[14.] Genovese, R. L. and Hauser, M. L. (1985) 'Superficial digital flexor tendinitis; Diagnosis using real-time ultrasound imaging', Journal of Equine Veterinary Science, 5(2), pp. 115-119. doi: 10.1016/S0737-0806(85)80058-7.

[15.] Gillis, C. L. (1997) 'Rehabilitation of Tendon and Ligament Injuries', the American Association of Equine Practitioners, 43, pp. 306-309.

[16.] Goodship, A. E., Birch, H. L. and Wilson, A. M. (1994) 'The pathobiology and repair of tendon and ligament injury.', The Veterinary clinics of North America. Equine practice, 10(2), pp. 323349. doi: 10.1016/S0749-0739(17)30359-0.

[17.] Gupta, A. K. et al. (1993) 'Comparative studies on biochemical indices in Thoroughbred horses of different age groups', Int. J. Anim. Sci, 8, pp. 263-265.

[18.] Harkins, J. D., Beadle, R. E. and Kamerling, S. G. (1993) 'The correlation of running ability and physiological variables in thoroughbred racehorses.', Equine veterinary journal. United States, 25(1), pp. 53-60. doi: 10.1111/j.2042-3306.1993.tb02902.x.

[19.] Ihedioha, J. I. and Chineme, C. N. (2004) Fundamentals of Systemic Veterinary Pathology, Vol 1. Great. Great AP Express Publishers Limited.

[20.] Jeffcott, L. B. et al. (1982) 'An assessment of wastage in Thoroughbred racing from conception to 4 years of age', Equine Veterinary Journal, 14(3), pp. 185-198. doi: 10.1111/j.20423306.1982.tb02389.x.

[21.] Kaneko, J. J. (1989) Clinical biochemistry of domestic animals. Academic Press Inc.

[22.] KRAUS-HANSEN, A. E. et al. (1992) 'Preliminary studies on the vascular anatomy of the equine superficial digital flexor tendon', Equine Veterinary Journal, 24(1), pp. 46-51. doi: 10.1111/j.2042-3306.1992.tb02778.x.

[23.] Lam, K. H. et al. (2007) 'Descriptive analysis of retirement of Thoroughbred racehorses due to tendon injuries at the Hong Kong Jockey Club (1992-2004)', Equine Veterinary Journal, 39(2), pp. 143-148. doi: 10.2746/042516407X159132.

[24.] Lindner, A. (2000) 'Use of blood biochemistry for positive performance diagnosis of sport horses in practice', pp. 611-618.

[25.] Marxen, S. et al. (2004) 'Intralesional polysulphated glycosaminoglycan as treatment of equine collagenase induced tendinitis: Clinical, ultrasonographic and histopathologic evaluation', Arquivo Brasileiro de Medicina Veterinaria e Zootecnia, 56(6), pp. 701-708. doi: 10.1590/s010209352004000600002.

[26.] McIlwraith, C. W. et al. (2018) 'Biomarkers for equine joint injury and osteoarthritis', Journal of Orthopaedic Research, 36(3), pp. 823-831. doi: 10.1002/jor.23738.

[27.] O'Sullivan, C. B. and Lumsden, J. M. (2013) Veterinary aspects of training Thoroughbred racehorses. Second Edi, Equine Sports Medicine and Surgery: Second Edition. Second Edi. Elsevier Ltd. doi: 10.1016/B978-0-7020-4771-8.00048-X.

[28.] Oikawa, M. A. and Kasashima, Y. (2002) 'The Japanese experience with tendonitis in racehorses', Journal of Equine Science, 13(2), pp. 41-56. doi: 10.1294/jes.13.41.

[29.] Patterson-Kane C., J. and Firth, E. C. (2009) 'The pathobiology of exercise-induced superficial digital flexor tendon injury in Thoroughbred racehorses', Veterinary Journal. Elsevier Ltd, 181(2), pp. 79-89. doi: 10.1016/j.tvj1.2008.02.009.

[30.] Patterson-Kane, J. C. et al. (1997) 'Comparison of collagen fibril populations in the superficial digital flexor tendons of exercised and nonexercised Thoroughbreds', Equine Veterinary Journal, 29(2), pp. 121-125. doi: 10.1111/j.2042-3306.1997.tb01653.x.

[31.] Patterson-Kane, J. C. et al. (1998) 'Exercise-related alterations in crimp morphology in the central regions of superficial digital flexor tendons from young Thoroughbreds: A controlled study', Equine Veterinary Journal, 30(1), pp. 61-64. doi: 10.1111/j.2042-3306.1998.tb04089.x.

[32.] Perkins, N. . R., Reid, S. W. J. and Morris, R. S. (2004) 'Pro ling the New Zealand Thoroughbred racing industry. 2 . Conditions interfering with training and racing AIM: To describe and enumerate conditions that interrupted', 53(1), pp. 69-76.

[33.] Persson, S. (1967) 'On blood volume and working capacity in horses. Studies of methodology and physiological and pathological variations.', Acta veterinaria Scandinavica. England, p. Suppl 19:9189. 
[34.] Pösö, A. R. (2002) 'Monocarboxylate transporters and lactate metabolism in equine athletes: A review', Acta Veterinaria Scandinavica, 43(2), pp. 63-74. doi: 10.1186/1751-0147-43-63.

[35.] Radostits, O. M., Blood, O. C. and Gay, C. C. (1994) Veterinanry Medicine. 8th Edn. Bailliere Tindall.

[36.] Ricketts, S. W. (2004) Hematologic and biochemical abnormalities in athletic horses, Equine Sports Medicine and Surgery. Elsevier Ltd. doi: 10.1016/B978-0-7020-2671-3.50047-7.

[37.] Rosalki, S. B. (1998) 'Low serum creatine kinase activity.', Clinical chemistry, 44(5), p. 905. doi: 10.1093/clinchem/44.5.905.

[38.] Schalm, O., Jain, N. and Carroll, E. (1975) Veterinary hematology. Philadelphia: Lea \& Febiger.

[39.] [39] Schalm, O. W., Jain, N. C. and Caroll, E. J. (1975) Veterinary Haematology. 3rd Edn. Lea and Febiger Philadelphia.

[40.] Siciliano, D. et al. (1995) 'Effect of conditioning and exercise type on serum creatine kinase and aspartate aminotransferase activity', 18, pp. 243-247.

[41.] Simundic, A.-M. et al. (2009) 'Comparison of visual vs. automated detection of lipemic, icteric and hemolyzed specimens: can we rely on a human eye?', Clinical chemistry and laboratory medicine. Germany, 47(11), pp. 1361-1365. doi: 10.1515/CCLM.2009.306.

[42.] Sjaastad, O., Sand, O. and Hove, K. (1997) 'Physiology of Domestic Animals. 2nd edition', Contemporary Accounting Research, 14(2), pp. 203-213. doi: 10.1111/j.19113846.1997.tb00533.x.

[43.] Sjaastad, O. V., Sand, O. and Hove, K. (2010) Physiology of Domestic Animals. 2nd edition. 2nd edn.

[44.] Smith, R. and Schramme, M. (2003) 'Tendon injury in the horse: Current theories and therapies', In Practice, 25(9), pp. 529-539. doi: 10.1136/inpract.25.9.529.

[45.] Snow, D. H. (1985) 'Biochemical basis of fatigue in racing animals and compounds that may influence performance by reflecting muscle metabolism', in In " Proc. 6th Int. Conf Racing Analysis and Veterinarians. Hong Kong, pp. 15-24.

[46.] Snow, D. H. and Harris, P. (1985) 'Enzymes as markers for the evaluation of physical fitness and training of racing horses', Adv. Clin. Enzymol, 6, pp. 251-258.

[47.] Thorpe, C. T., Clegg, P. D. and Birch, H. L. (2010) 'A review of tendon injury: Why is the equine superficial digital flexor tendon most at risk?', Equine Veterinary Journal, 42(2), pp. 174-180. doi: $10.2746 / 042516409 X 480395$.

[48.] Wang, J. H. C., Iosifidis, M. I. and Fu, F. H. (2006) 'Biomechanical basis for tendinopathy', Clinical Orthopaedics and Related Research, (443), pp. 320-332. doi: 10.1097/01.blo.0000195927.81845.46.

[49.] Watson, R. (2016) 'Reading and interpreting equine blood analyses', Equine Health, 2016(30), pp. 38-41. doi: 10.12968/eqhe.2016.30.38. 